\title{
Investigation of Mixing and Compaction Temperatures of Modified Hot Asphalt and Warm Mix Asphalt
}

\author{
Ali Almusawi ${ }^{1 *}$, Burak Sengoz ${ }^{2}$, Ali Topal $^{2}$ \\ ${ }^{1}$ Graduate School of Natural and Applied Sciences, Dokuz Eylul University, 35160 Buca, Izmir, Turkey \\ 2 Department of Civil Engineering, Faculty of Engineering, Dokuz Eylul University, 35160 Buca, Izmir, Turkey \\ * Corresponding author, e-mail: ali.almusawi@ogr.deu.edu.tr
}

Received: 16 October 2019, Accepted: 15 September 2020, Published online: 08 October 2020

\begin{abstract}
The determination of mixing and compaction temperatures through the Equiviscous method has been defined as the standard method and it is designed for the base bitumen (unmodified bitumen) based on the viscosity measurements. The implementation of the Equiviscous method for the modified bitumen resulted in high mixing and compaction temperatures which may not be required during the construction of the asphalt mixtures. This study aims to investigate several alternative methods proposed in the literature named as high shear rate method, zero shear viscosity method, steady shear flow method, and phase angle method. Besides, the obtained mixing and compaction temperatures results are compared with the standard (equiviscous) method. For this purpose, 50/70 penetration grade bitumen modified with 5 \% elastomeric type - Styrene Butadiene Styrene (SBS), and 1.5 \% Reactive Elastomeric Terpolymer type - Elvaloy (RET) has been used. The study also aims to measure the applicability of the proposed alternative methods for the warm mix asphalt involving organic and chemical additives. The results have shown that for the polymer modified bitumen, the application of all proposed methods in the literature resulted in lower mixing and compaction temperatures compared to the Equiviscous method. While for the warm mix asphalt, the implementation of the steady shear flow method resulted in lesser temperatures compared to the Equiviscous method.
\end{abstract}

Keywords

mixing and compaction, high shear rate, zero shear viscosity, steady shear flow, phase angle

\section{Introduction}

In 1962 the Asphalt Institute's Mix Design Methods for Asphalt Concrete Manual suggested specifying mixing and compaction temperatures based on viscosity measurements. The viscosity limits were $85 \pm 10$ seconds Saybolt Furol for mixing the bitumen with aggregate and $140 \pm 15$ seconds Saybolt Furol for compaction. By 1974 the Asphalt Institute changed the units of the viscosity to more practical units of centistokes and suggested the viscosity limits to be $170 \pm 20$ centistokes and $280 \pm$ 30 centistokes for mixing and compaction respectively. Twenty years later, Superpave mix design (SP-2) Manual suggested using the same mixing and compaction limits only the viscosity unit has been changed to become Pa. s. The manual has stated that the suggested limits are not applicable for the modified bitumen and proposed that users must contact the supplier for appropriate mixing and compaction temperature values [1].
American Society for Testing and Materials (ASTM) has released a special standard to calculate mixing and compaction temperatures of asphalt mixture (ASTM D2493) [2]. In this standard, the viscosity measurement must be conducted at specified temperatures $\left(135^{\circ} \mathrm{C}\right.$ and $\left.165^{\circ} \mathrm{C}\right)$ and the obtained viscosities in log scale are drawn against the temperature. The mixing and compaction temperatures limits are $0.17 \pm 0.02 \mathrm{~Pa}$. s and $0.28 \pm 0.03 \mathrm{~Pa}$. s, respectively.

Since the Equiviscous method (ASTM D2493) is based on viscosity measurement for unmodified bitumen, the increase in viscosity in polymer modified bitumen will affect mixing and compaction temperatures determination and may result in excessive temperatures. In other words, the application of the Equiviscous method may not present realistic approach regarding mixing and compaction of modified bitumen. So it is necessary to investigate alternative methods that must be reliable and more applicable [3-5]. 
Some studies have suggested measuring the viscosity of the asphalt mastic (bitumen and filler) rather than the base bitumen to determine the mixing and compaction temperatures. The reason to use asphalt mastic is to better simulate the mixing of aggregate and bitumen during the construction. Zeng and $\mathrm{Wu}[6]$ investigated the effect of the mineral filler on the viscosity of the bitumen and also on the mixing and compaction temperatures. They believed that the viscosity of the asphalt mastic must be considered rather than the bitumen itself. They suggested new viscosity rang for mixing and compaction for unmodified bitumen $0.576 \pm 0.071 \mathrm{~Pa}$. s. and $0.968 \pm 0.107 \mathrm{~Pa}$. s, respectively.

Other studies have demonstrated the effects of the compaction temperature on the properties of the asphalt mixtures. Azari et. al [7] evaluated the optimum compaction temperature for Novophalt modified bitumen using four temperatures $\left(119,139,159\right.$, and $\left.179^{\circ} \mathrm{C}\right)$. They found that increasing the compaction temperature to some degree improves the shear properties of the mixture and the optimum compaction temperature range is between 139 to $159{ }^{\circ} \mathrm{C}$. Lee et. al [8] investigated the effects of using different compaction temperatures on the volumetric properties of the modified bitumen. Two modification types (crumb rubber and SBS) have been used to prepare the modified bitumen samples and have been compacted over a range of temperatures $\left(116,135,154,173^{\circ} \mathrm{C}\right)$. The results have shown that for SBS modified bitumen the variation of the compaction temperatures does not affect the volumetric properties. While for the crumb rubber modified bitumen the volumetric properties have influenced by the variation of the compaction temperatures. Also, it has been noticed that the air void content has increased with decreasing the compaction temperature [9-11].

This study aims to measure the applicability of new alternative methods which are proposed in the literature for both hot and warm mix asphalt mixtures and to compare the results with the Equiviscous method (ASTM D2493).

\section{Experimental}

\subsection{Materials}

In this study, base bitumen with 50/70 grade has been supplied by Dere Asphalt Inc. The major characteristics of the base bitumen have been evaluated through some conventional tests such as penetration test, softening point test and rolling thin film oven test. Table 1 presents the properties of the base bitumen used in the study.
Table 1 Properties of the base bitumen

\begin{tabular}{|c|c|c|c|}
\hline Test & Specification & Results & $\begin{array}{l}\text { Specification } \\
\text { limits }\end{array}$ \\
\hline Penetration $\left(25^{\circ} \mathrm{C} ; 0.1 \mathrm{~mm}\right)$ & $\begin{array}{l}\text { ASTM D5-06 } \\
{[12]}\end{array}$ & 65 & $50-70$ \\
\hline Softening point $\left({ }^{\circ} \mathrm{C}\right)$ & $\begin{array}{c}\text { ASTM D36 } \\
{[13]}\end{array}$ & 51 & $46-54$ \\
\hline Ductility $\left(25^{\circ} \mathrm{C} ; \mathrm{cm}\right)$ & $\begin{array}{c}\text { ASTM D113 } \\
{[14]}\end{array}$ & 100 & - \\
\hline Specific gravity & $\begin{array}{l}\text { ASTM D70 } \\
{[15]}\end{array}$ & 1.030 & - \\
\hline Flash point $\left({ }^{\circ} \mathrm{C}\right)$ & $\begin{array}{c}\text { ASTM D92 } \\
{[16]}\end{array}$ & $260+$ & 230 (min) \\
\hline Penetration index (PI) & - & 0.35 & - \\
\hline $\begin{array}{l}\text { Rolling thin film oven test } \\
\text { (RTFOT) }\end{array}$ & $\begin{array}{c}\text { ASTM } \\
\text { D2872-12 [17] }\end{array}$ & & \\
\hline Change of mass $(\%)$ & - & 0.160 & 0.5 (max.) \\
\hline $\begin{array}{l}\text { Penetration after RTFOT } \\
\left(25^{\circ} \mathrm{C} ; 0.1 \mathrm{~mm}\right)\end{array}$ & $\begin{array}{l}\text { ASTM D5-06 } \\
{[12]}\end{array}$ & 53 & 50 (min.) \\
\hline $\begin{array}{l}\text { Retained penetration after } \\
\text { RTFOT }(\%)\end{array}$ & $\begin{array}{l}\text { ASTM D5-06 } \\
{[12]}\end{array}$ & 82 & 50 (min.) \\
\hline $\begin{array}{l}\text { Softening point after } \\
\text { RTFOT }\left({ }^{\circ} \mathrm{C}\right)\end{array}$ & $\begin{array}{c}\text { ASTM D36 } \\
{[13]}\end{array}$ & 58 & 48 (min.) \\
\hline
\end{tabular}

Two bitumen modifier types, elastomeric type - Styrene Butadiene Styrene (SBS), and Reactive Elastomeric Terpolymer type - Elvaloy RET, were used. The SBS polymer was Kraton D-1101 (powder form) supplied by the Shell Chemicals Company. Reactive Elastomeric Terpolymer type was Elvaloy ${ }^{\circledR} 4170$ supplied in pellet form by DuPont, USA. The polymer modifiers play a major role in improving the asphalt mixture characteristics and increase the service life of the flexible pavement The properties of both Kraton D-1101 and Elvaloy ${ }^{\circledR} 4170$ polymer are presented in Table 2. In order to prepare warm mix asphalt samples, two types of additives organic (Sasobit ${ }^{\mathbb{B}}$ ) and chemical (Rediset ${ }^{\circledR}$ ) have been used. The organic WMA additive, which has been supplied from a South African Company, is a long-chain aliphatic polymethylene hydrocarbon produced from the Fischer-Tropsch chemical process with a melting temperature of $120^{\circ} \mathrm{C}$. The longer chains help keep the wax in solution, which reduces bitumen viscosity at typical asphalt production and compaction temperatures. Chemical WMA additive is a combination of cationic surfactants and organic additive-based rheology modifier. The additive chemically modifies the bitumen and obtains active adhesion force that improves coating of aggregates with bitumen [18-23]. 
Table 2 The properties of Kraton ${ }^{\circledR}$ D-1101 and Elvaloy $® 4170$ polymer

\begin{tabular}{|c|c|c|c|}
\hline Composition & Specification & $\begin{array}{c}\text { Kraton }{ }^{\circledR} \\
\text { D } 1101\end{array}$ & $\begin{array}{c}\text { Elvaloy }{ }^{\circledR} \\
4170\end{array}$ \\
\hline \multirow[t]{2}{*}{ Molecular structure } & - & Linear & Linear \\
\hline & Physical properties & & \\
\hline Specific gravity & ASTM D792 [24] & 0.94 & - \\
\hline $\begin{array}{l}\text { Tensile strength at } \\
\text { break (MPa) }\end{array}$ & ASTM D 412 [25] & 31.8 & 31.8 \\
\hline Shore hardness (A) & ASTM D 2240 [26] & 71 & - \\
\hline Physical form & - & $\begin{array}{l}\text { Powder, } \\
\text { pellet }\end{array}$ & $\begin{array}{l}\text { Powder, } \\
\text { pellet }\end{array}$ \\
\hline Melt flow rate & ASTM D-1238 [27] & $<1$ & 8 \\
\hline $\begin{array}{l}\text { Processing } \\
\text { temperature }\left({ }^{\circ} \mathrm{C}\right)\end{array}$ & - & $150-170$ & - \\
\hline Elongation at break (\%) & ASTM D 412 [24] & 875 & - \\
\hline Density & - & - & 0.557 \\
\hline
\end{tabular}

\subsection{Preparation of modified bitumen samples}

Based on the past researches the SBS Kraton ${ }^{\circledR}$ D 1101 concentration in the base bitumen is chosen $5 \%$ as optimum content [28]. A high shear laboratory mixer is used to prepare the SBS polymer modified bitumen. The base bitumen has been first heated to $\left(180-185^{\circ} \mathrm{C}\right)$ and has been poured into $600 \mathrm{ml}$ glass beakers. Based on several past researches, the base bitumen and the polymer are heated at such temperature to ensure that the base bitumen and polymer are above their softening points. Also, it is necessary to heat the bitumen at high temperatures to allow the polymer particles to become soluble during production [29-32]. The SBS was then added gradually to the base bitumen and the rotating speed was kept at $2000 \mathrm{rpm}$ for 1 hour.

The Elvaloy content is $1.5 \%$ of the bitumen weight as recommended in the literature to achieve optimum performance [33]. Laboratory mixer is used to prepare the modified bitumen samples and following the procedure recommended by the DuPont company. The bitumen is heated at $185^{\circ} \mathrm{C}$ to become fluid enough and then the modifier is gradually added while the rotating speed is set at $200 \mathrm{rpm}$ for 2 hours. The viscosity must be measured immediately after the finishing of the production and the sample must be cured in the oven for 24 hours at $190{ }^{\circ} \mathrm{C}$ to allow the reaction to complete [34].

\subsection{Production of warm mix asphalt samples}

The concentration of both organic and chemical is specified based on the recommendations by the suppliers as well as literature [35]. The concentration of both organic additive (Sasobit ${ }^{\mathbb{B}}$ ) and the chemical additive (Rediset ${ }^{\mathbb{B}}$ ) is chosen as $3 \%$ to produce warm mix asphalt samples.
The base bitumen is heated until it becomes fluid and has been poured into a $500 \mathrm{ml}$ glass beaker. The Sasobit ${ }^{\circledR}$ is then added gradually and the rotating speed was maintained at $1000 \mathrm{rpm}$ for 10 minutes. While for the chemical additive the rotating speed was $1000 \mathrm{rpm}$ for $15 \mathrm{~min}$ utes. These values were taken into account based on past researches which indicate that the production process of the warm mix asphalt does not require a high shear rate and the required production time should be maintained at the minimum so the warm mix additives would more effective and the aging effect would be avoided [36-37].

\subsection{Test methods}

\subsubsection{Conventional bitumen test}

Conventional bitumen tests such as penetration test (ASTM D5- 06) [12], softening point test (ASTM D36-95) [13] and rolling film thin oven test (ASTM D2872-12) [17] have been subjected on the base bitumen and also on both PMB and WMA samples. Table 3 presents the properties of the polymer modified bitumen and bitumen involving WMA additives.

As seen in Table 3, there is a significant decrease in the penetration values and a considerable increase in the softening point temperatures to each PMB and WMA samples. The increase in softening point is favorable since bitumen with a higher softening point is less susceptible to

Table 3 Conventional properties of polymer modified bitumen and bitumen involving WMA additives

\begin{tabular}{|c|c|c|c|c|c|}
\hline \multirow{2}{*}{ Additive type } & \multirow{2}{*}{$\begin{array}{c}\text { Base } \\
\text { bitumen }\end{array}$} & \multicolumn{2}{|c|}{ Polymer } & \multicolumn{2}{|c|}{ WMA } \\
\hline & & SBS & Elvaloy & Organic & Chemical \\
\hline Content (\%) & 0 & 5 & 1.5 & 3 & 3 \\
\hline \multicolumn{6}{|l|}{ Property } \\
\hline $\begin{array}{l}\text { Penetration ( } 25 \\
\left.{ }^{\circ} \mathrm{C} ; 0.1 \mathrm{~mm}\right)\end{array}$ & 65 & 52 & 49 & 37 & 40 \\
\hline $\begin{array}{l}\text { Softening point } \\
\left({ }^{\circ} \mathrm{C}\right)\end{array}$ & 51 & 77.9 & 65 & 69.3 & 58.0 \\
\hline $\begin{array}{l}\text { Penetration } \\
\text { index (PI) }\end{array}$ & 0.35 & 2.18 & 1.92 & 1.95 & 0.09 \\
\hline \multicolumn{6}{|l|}{$\begin{array}{l}\text { Rolling thin } \\
\text { film oven test } \\
\text { (RTFOT) }\end{array}$} \\
\hline $\begin{array}{l}\text { Change of mass } \\
(\%)\end{array}$ & 0.160 & 0.090 & 0.030 & 0.07 & 0.08 \\
\hline $\begin{array}{l}\text { Penetration ( } 25 \\
\left.{ }^{\circ} \mathrm{C} ; 0.1 \mathrm{~mm}\right)\end{array}$ & 53 & 41 & 38 & 31 & 33 \\
\hline $\begin{array}{l}\text { Retained } \\
\text { penetration }(\%)\end{array}$ & 82 & 79 & 65 & 15 & 17 \\
\hline $\begin{array}{l}\text { Softening point } \\
\left({ }^{\circ} \mathrm{C}\right)\end{array}$ & 58 & 70 & 64 & 73.6 & 60.1 \\
\hline
\end{tabular}


permanent deformation (rutting) [28]. Also, all of the additives reduce temperature susceptibility (as determined by the penetration index - PI) of the bitumen. Lower values of PI indicate higher temperature susceptibility. The age hardening of the bitumen during bulk storage is evaluated by the mass loss, penetration, retained penetration and softening point temperature in the RTFOT. The mass losses corresponding to each PMB and WMA samples are almost identical and within specification limits (0.5 max. based on Turkish standards). This result indicates that PMB and WMA samples are not affected by aging in the RTFOT which simulates the aging (hardening) of bitumen during the bulk storage period.

\subsubsection{Mixing and compaction temperatures methodologies}

In the last few years, there are several attempts by many researchers to specify a more practical approach to determine mixing and compaction temperatures for modified bitumen rather than the Equiviscous method (ASTM D 2493). Below are the detailed information regarding the proposed as well as the traditional method.

- Equiviscous method (ASTM D 2493)

Based on ASTM D 2493, this method is conducted to measure the viscosity of the bitumen at two temperatures $135^{\circ} \mathrm{C}$ and $165^{\circ} \mathrm{C}$ at a constant shear rate of $6.8 \mathrm{1} / \mathrm{s}$. Brookfield viscometer is the most common machine that is utilized to measure the bitumen viscosity for this method. The measured viscosity results are then drawn versus the temperature. The temperatures corresponding to bitumen viscosities $0.17 \pm 0.02 \mathrm{~Pa}$. s and $0.28 \pm 0.03 \mathrm{~Pa}$. s were chosen as mixing and compaction temperatures, respectively.

- High shear rate method (HSR) (original and evolution) This approach has been introduced based on the shear rate- temperature behavior dependency of the bitumen. The hypothesis of this method is based on the high shear rate developing through the compaction of the specimen in a Superpave gyratory compactor (SGC). In this method, Brookfield viscometer is used to find the viscosity of the bitumen at different shear rates and then drawn and extrapolated using the power-law model to $5001 / \mathrm{s}$ shear rate. This is performed because such a high shear rate cannot be measured directly using Brookfield viscometer. Based on the bitumen viscosity range used to estimate mixing and compaction temperatures, this method can be classified into two forms named high shear rate original (HSR-O) and high shear rate evolution (HSR-E). In HSR-O method the obtained viscosity values at $135{ }^{\circ} \mathrm{C}$ and $165{ }^{\circ} \mathrm{C}$ are plotted against the temperature. Mixing and compaction temperatures are determined by using the same viscosity limits used in the Equiviscous method $(0.17 \pm 0.02 \mathrm{~Pa}$. s and $0.28 \pm 0.03 \mathrm{~Pa}$. s) [3]. While for HSR-E method They have suggested a higher viscosity range for mixing and compaction to be used which are $0.275 \pm 0.03 \mathrm{~Pa}$. s and $0.550 \pm 0.06 \mathrm{~Pa}$. s, respectively [38].

\section{- Zero shear viscosity method (ZSV)}

Zero shear viscosity (ZSV) is the viscosity measured in shear deformation at a shear rate approaching zero. Khatri [4] proposed the zero shear viscosity concept to be implemented for the determination of mixing and compaction temperatures of modified bitumen using Brookfield viscometer. In order to find the zero shear viscosity, the Cross Williamson model has been proposed to be used in a solver program. Accordingly, unlike the Equiviscous method, different shear rate values are required to measure the viscosity of the modified bitumen at two temperatures $135{ }^{\circ} \mathrm{C}$ and $165{ }^{\circ} \mathrm{C}$. The required mixing and compaction temperatures are then found by plotting the $\log$-log of viscosity as a function of log temperature in degrees Kelvin $\left(273+{ }^{\circ} \mathrm{C}\right)$. The proposed bitumen viscosity ranges to estimate mixing and compaction is $3.0 \mathrm{~Pa}$. $\mathrm{s}$ and 6.0 Pa. s, respectively. The Cross Williamson model is given as in Eq. (1) [4].

$\eta=\eta_{\infty}+\left(\eta_{0}-\eta_{\infty}\right) /(1+[(k \dot{\gamma})] \wedge n)$

where,

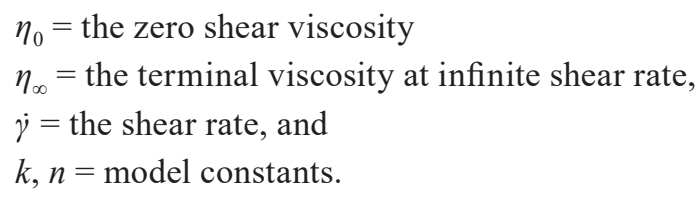

\section{- Steady shear flow method (SSF)}

This method which is recommended by Reinke is based on the shear dependency of the bitumen. The steady shear flow test is conducted using Dynamic Shear Rheometer (DSR). The target shear stress of 500 Pascal is chosen as a value where the viscosity measurements appeared more stable and the bitumen sample reaches the steady-state condition. In this method, Viscosities are measured at three temperatures $\left(76^{\circ} \mathrm{C}, 82^{\circ} \mathrm{C}\right.$, and $\left.88^{\circ} \mathrm{C}\right)$ over a series of stress levels from $0.33 \mathrm{~Pa}$ to $500 \mathrm{~Pa}$. The measured viscosity values at steady state-condition $(500 \mathrm{~Pa})$ are then plotted using a log viscosity versus log temperature chart and extrapolated to determine the mixing and compaction temperatures based upon specified viscosity ranges of $0.17 \pm 0.02 \mathrm{~Pa}$. s and $0.35 \pm 0.03 \mathrm{~Pa}$. s, respectively [39]. 


\section{- Phase angle method}

This method is based on non-Newtonian viscoelastic behavior of the bitumen. In this method, the bitumen sample is tested using the frequency sweep module of DSR. Based on the penetration grade of the bitumen as well as the concentration of polymer, different test temperatures varying from $40{ }^{\circ} \mathrm{C}$ to $100{ }^{\circ} \mathrm{C}$ can be applied. Frequency ranges are $0.1 \mathrm{rad} / \mathrm{sec}$ to $100 \mathrm{rad} / \mathrm{sec}$ and the strain level is maintained at $12 \%$. Phase angle master curves are developed from the obtained data using a reference temperature of $80^{\circ} \mathrm{C}$ through the Time-Temperature Superposition (TTS) procedure. The phase angle of $86^{\circ}$ is recommended since the values between $85^{\circ}$ to $90^{\circ}$ exhibits the viscous behavior of bitumen sample. As indicated in Eqs. (2) and (3) the frequency value which corresponds $86^{\circ}$ phase angle is used in an empirical equation that has been established by Casola to determine mixing and compaction temperatures of the bitumen [5].

Mixing Temperature $=325(\text { freq. })^{-0.0135}$,

Compaction Temperature $=300(\text { freq. })^{-0.012}$,

where the frequency, is in radians/sec.

\section{Results and discussion}

\subsection{Determination of Mixing and Compaction Temperatures methods}

\subsubsection{Equiviscous method (ASTM D 2493)}

Fig. 1 illustrates the measured viscosity at $135^{\circ} \mathrm{C}$ and $165^{\circ} \mathrm{C}$ regarding SBS and Elvaloy polymer modified bitumen as well as bitumen samples involving WMA additives (organic and chemical).

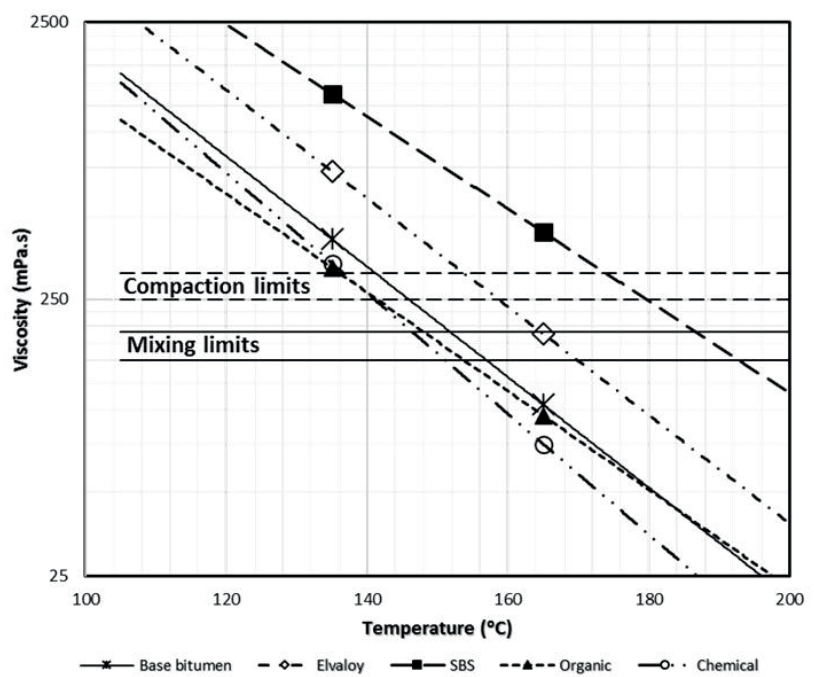

Fig. 1 Equiviscous method
The mixing and compaction temperatures corresponding to $0.17 \pm 0.02 \mathrm{~Pa}$. $\mathrm{s}$ and $0.28 \pm 0.03 \mathrm{~Pa}$. s are presented in Table 4. The results showed that the polymer modified bitumen samples tend to have a higher mixing and compaction temperatures than the base bitumen. This can be attributed to the significant physical changes when the polymer is added to the base bitumen. The polymer absorbs the oily constituents and especially at higher concentration the bitumen becomes stiffer and more viscous. On the other hand, both warm mix asphalt additive work on reducing the viscosity of the bitumen samples so the required mixing and compaction temperatures become lesser than the base bitumen.

\subsubsection{High Shear Rate method (HSR) (original and evolution)}

Figs. 2-3 present the viscosity values plotted against shear rate related to base bitumen, polymer modified bitumen, and bitumen samples produced with WMA additives. The measured viscosity values are then extrapolated using the power law model. For polymer modified bitumen samples (Fig. 2), the viscosity values measured by Brookfield viscometer are shear rate and temperature-dependent.

Table 4 Equiviscous method results

\begin{tabular}{lcc}
\hline Material & Mixing Temperature $\left({ }^{\circ} \mathrm{C}\right)$ & $\begin{array}{c}\text { Compaction } \\
\text { Temperature }\left({ }^{\circ} \mathrm{C}\right)\end{array}$ \\
\hline Base bitumen & $152-158$ & $141-146$ \\
PMB (SBS) & $186-192$ & $174-180$ \\
PMB (Elvaloy) & $165-170$ & $154-158$ \\
WMA (Organic) & $146-153$ & $135-140$ \\
WMA (Chemical) & $146-151$ & $136-141$ \\
\hline
\end{tabular}

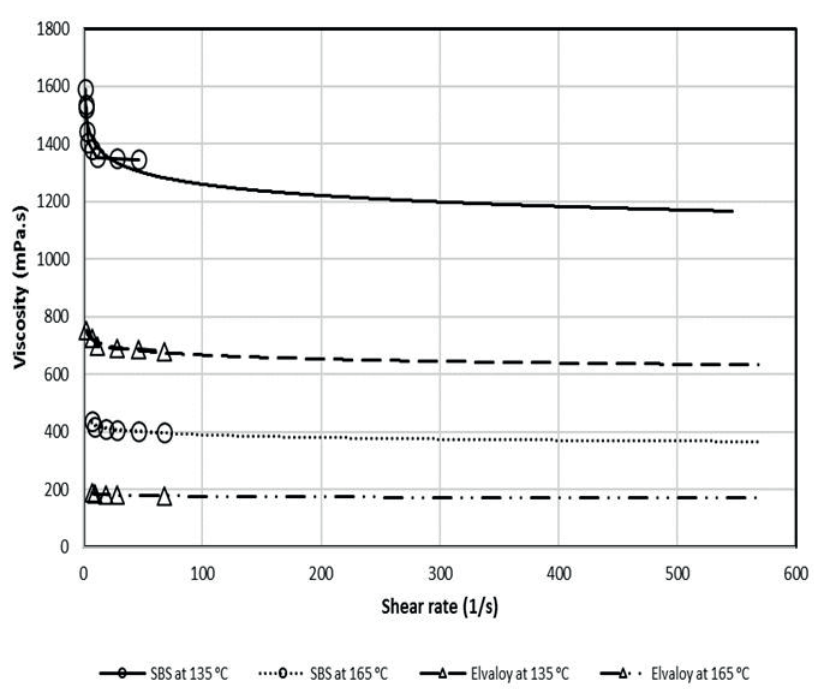

Fig. 2 High shear rate method for SBS and Elvaloy (PMB) 


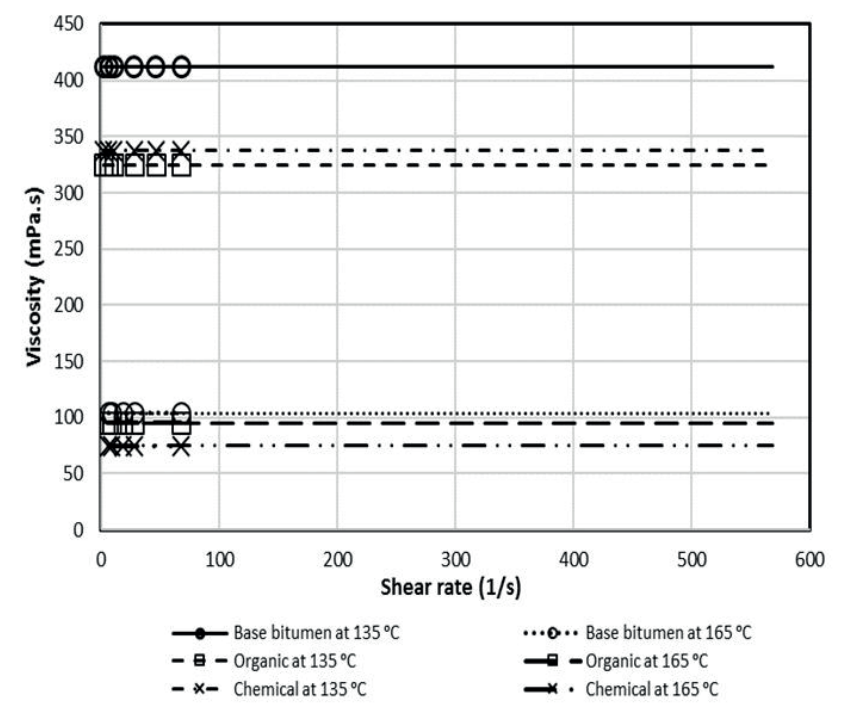

Fig. 3 High shear rate method for Base bitumen and WMA

This behavior is generally detected when polymers are mixed with bitumen and is designated as non-Newtonian behavior. While the base bitumen and WMA samples demonstrated a clear Newtonian behavior as depicted in Fig. 3. In this behavior, the bitumen samples at elevated temperatures are not affected by any variation in the shear rate implemented.

With the aim of determining mixing and compaction temperatures, the measured values of viscosity are extrapolated to find the viscosity at shear rate value at $500 \mathrm{1} / \mathrm{s}$ using the power law model. the extrapolated viscosity values at $500 \mathrm{1} / \mathrm{s}$ shear rate are drawn against the temperature as demonstrated in Figs. 4 and 5 for both original and evolution form of high shear rate method. For the HSR-O the mixing and compaction temperatures are determined using the same standard limits specified in the Equiviscous method ( $0.17 \pm 0.02 \mathrm{~Pa}$. s and $0.28 \pm 0.03$ Pa. s). For HSR-O, different mixing and compaction temperatures levels are applied $(0.275 \pm 0.03 \mathrm{~Pa}$. s and $0.550 \pm 0.06 \mathrm{~Pa}$. s).

The above-mentioned method is based on the variation in viscosity with change in shear rate. In other words, this method is more suitable for non-Newtonian materials such as polymer modified bitumen. It can be noticed that the original form of the method resulted in close results

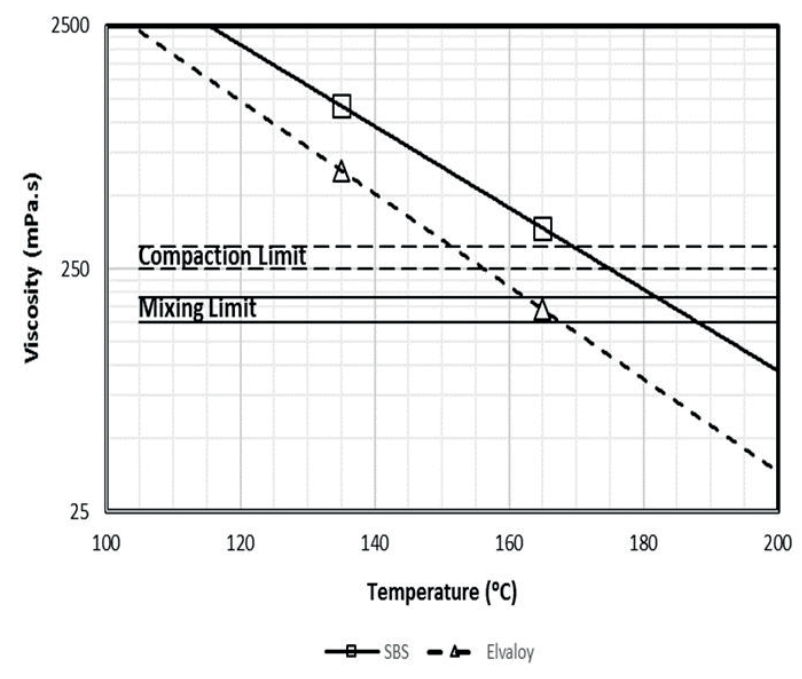

Fig. 4 High Shear Rate Method (Original form)

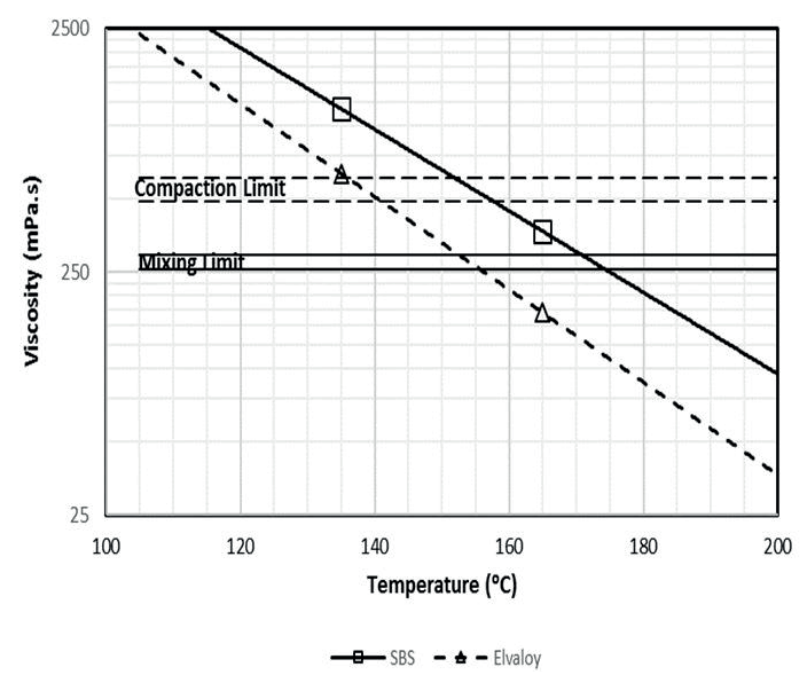

Fig. 5 High Shear Rate Method (Evolution form)

with a slight different compare to the Equiviscous method. While utilizing the evolution form exhibited lower mixing and compaction temperatures. Among the polymer modified samples, SBS polymer depicted the highest mixing and compaction temperatures. This method is not applicable on base bitumen and on bitumen involving WMA additives since they all depict Newtonian behavior. Based on Figs. 2-5, the determined mixing and compaction are presented in Table 5.

Table 5 HSR method results

\begin{tabular}{|c|c|c|c|c|c|c|}
\hline & & Base bitumen & PMB (SBS) & PMB (Elvaloy) & WMA (Organic) & WMA (Chemical) \\
\hline \multirow{2}{*}{ Mixing Temperature $\left({ }^{\circ} \mathrm{C}\right)$} & HSR-O & NB* & $181-187$ & $162-167$ & NB* & $\mathrm{NB}^{*}$ \\
\hline & HSR-E & $\mathrm{NB}^{*}$ & $170-175$ & $152-155$ & $\mathrm{NB}^{*}$ & $\mathrm{NB}^{*}$ \\
\hline \multirow{2}{*}{ Compaction Temperature $\left({ }^{\circ} \mathrm{C}\right)$} & HSR-O & $\mathrm{NB}^{*}$ & $170-175$ & $152-157$ & NB* & NB* \\
\hline & HSR-E & $\mathrm{NB}^{*}$ & $152-158$ & $136-141$ & $\mathrm{NB}^{*}$ & NB* \\
\hline
\end{tabular}

*Newtonian Behavior 


\subsubsection{Zero Shear Viscosity method (ZSV)}

Similar to the high shear rate method the viscosity values are measured at different shear rates at two temperatures $135{ }^{\circ} \mathrm{C}$ and $165{ }^{\circ} \mathrm{C}$. Figs. 6-7 illustrate the measured and the fitted (obtained from Cross-Williamson model) viscosity values at different shear rates for base bitumen and SBS and Elvaloy polymer modified samples as well as to the WMA bitumen samples.

The resulted zero shear viscosity is plotted on a log$\log$ scale as a function of log temperature in Kelvin units as illustrated in Fig. 8. The mixing and compaction temperatures corresponding to $3 \pm 0.3 \mathrm{~Pa} \mathrm{~s}$ and $6 \pm 0.6 \mathrm{~Pa} \mathrm{~s}$, respectively.

The results for both polymers modified samples have clearly depicted lower mixing and compaction temperatures compared to the Equiviscous method as illustrated

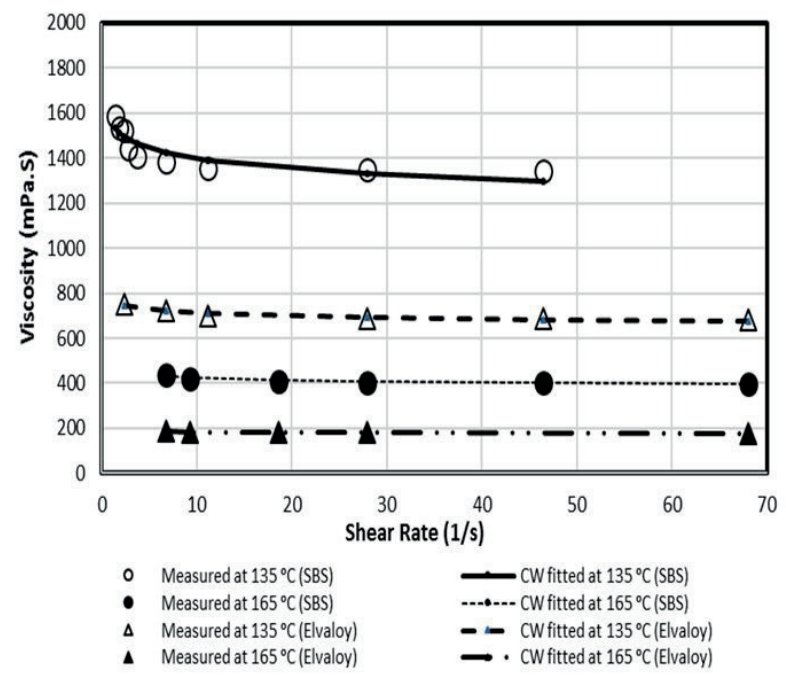

Fig. 6 Zero shear viscosity method for SBS and Elvaloy

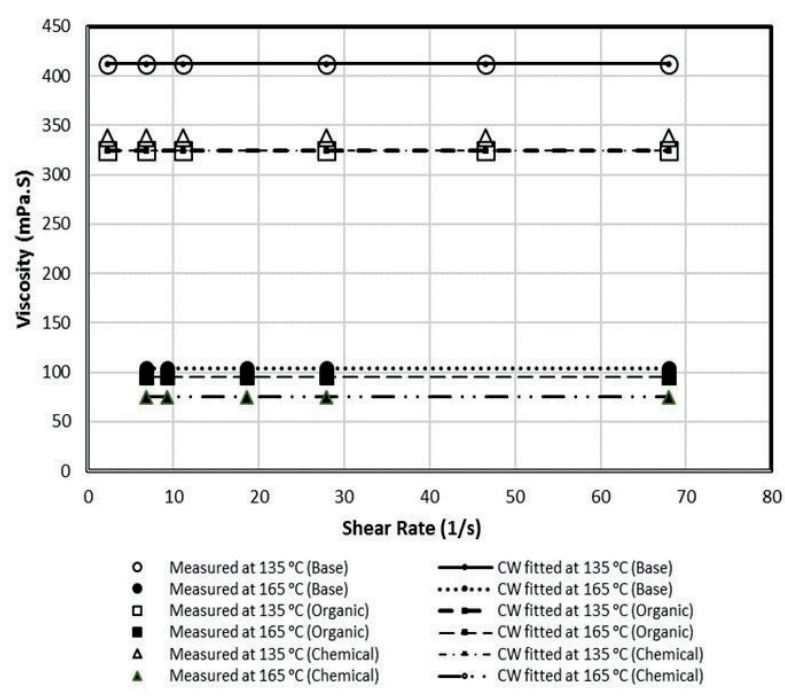

Fig. 7 Zero shear viscosity method for Base bitumen and WMA

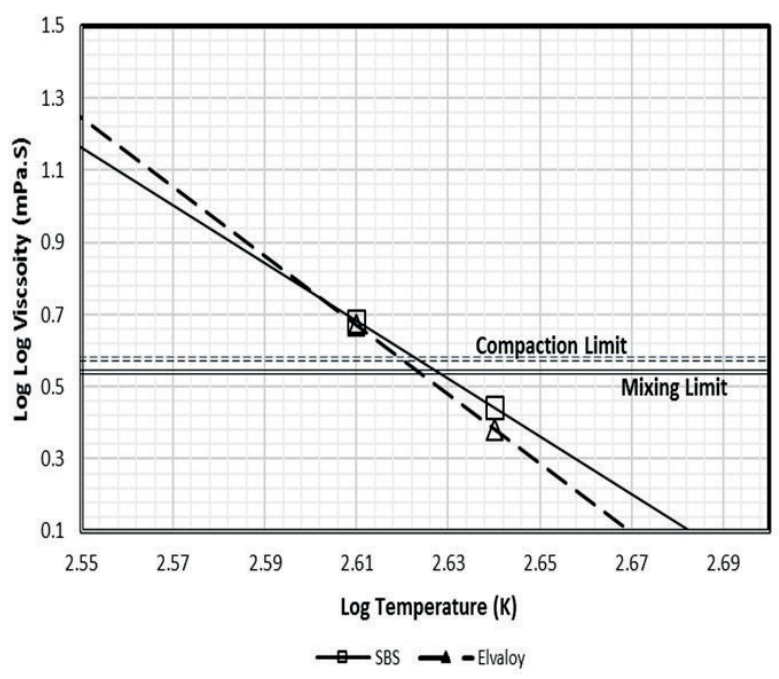

Fig. 8 Mixing and compaction determination for ZSV method

Table 6 ZSV method results

\begin{tabular}{lcc}
\hline Material & Mixing temperature $\left({ }^{\circ} \mathrm{C}\right)$ & $\begin{array}{c}\text { Compaction } \\
\text { temperature }\left({ }^{\circ} \mathrm{C}\right)\end{array}$ \\
\hline Base bitumen & $\mathrm{NB}^{*}$ & $\mathrm{NB}^{*}$ \\
PMB (SBS) & 151.5 & 145.5 \\
PMB (Elvaloy) & 148.7 & 141.9 \\
WMA (Organic) & $\mathrm{NB}^{*}$ & $\mathrm{NB}^{*}$ \\
WMA (Chemical) & $\mathrm{NB}^{*}$ & $\mathrm{NB}^{*}$ \\
\hline
\end{tabular}

*Newtonian Behavior

in Table 6. On the other hand, the implementation of this method for the base and WMA bitumen samples is not suitable and this ascribed to the Newtonian behavior of such materials.

\subsubsection{Steady Shear Flow method (SSF)}

Figs. 9-13 present the test results for different bitumen samples at different set of temperatures $\left(76^{\circ} \mathrm{C}, 82^{\circ} \mathrm{C}\right.$, and $88^{\circ} \mathrm{C}$ ). All the bitumen samples have reached a steadystate condition (no variation in the viscosity readings) when the stress level is about $500 \mathrm{~Pa}$. Based on Figs. 9-10, the viscosity of PMB samples are more susceptible to the variation in both temperature and the applied stress. This may be attributed to the Non-Newtonian behavior of the PMB. In other words, the viscosity of such fluid is more sensitive and dependent on the change in the shear applied. The PMB samples generally tend to have shear thinning behavior in which the viscosity is decreased by increasing the shear stress.

On the other hand, for the base bitumen sample (Fig. 11), the viscosity values tended to be uniform and invariable regardless of the applied stress or temperature which is assigned to the Newtonian behavior of the base bitumen. 


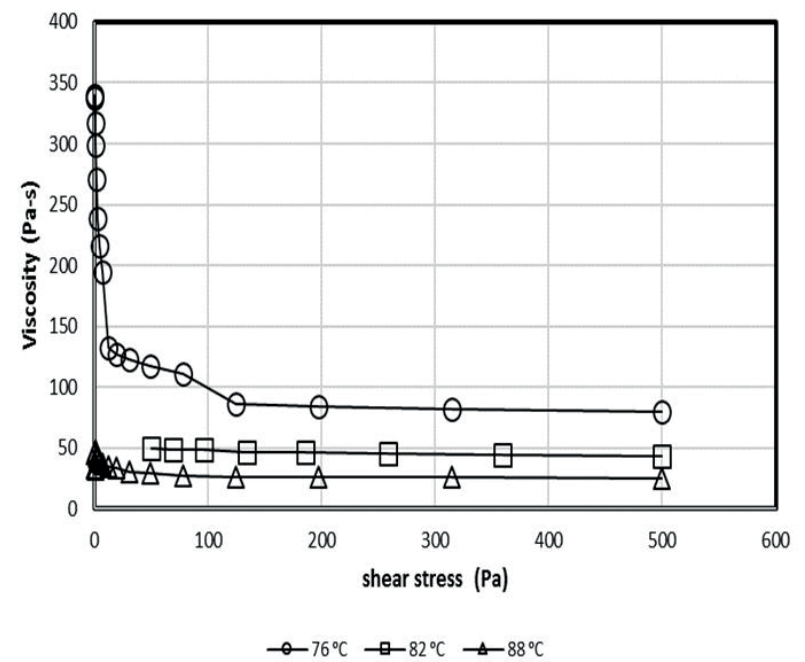

Fig. 9 Steady shear flow method for PMB (SBS)

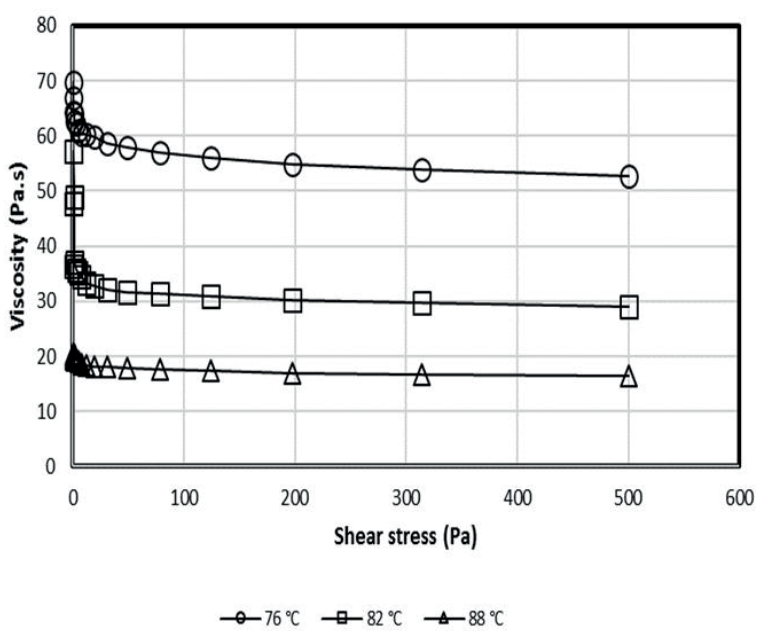

Fig. 10 Steady shear flow method for PMB (Elvaloy)

While for WMA samples (Figs. 12-13), the obtained viscosity values were varied with the change in the applied stresses and temperatures. It has been noticed that the detected behavior was not Newtonian and the viscosity value decreased with the increase of the shear stress. This can be attributed to the sensitivity of the Dynamic Shear Rheometer (DSR) machine which used to perform this test and also to the low range of temperatures $\left(76^{\circ} \mathrm{C}, 82^{\circ} \mathrm{C}\right.$, and $88^{\circ} \mathrm{C}$ ) utilized in this method.

In order to obtain the mixing and compaction temperatures, the viscosity values at steady-state condition are plotted and extrapolated against the temperature as illustrated in Fig. 14.

The obtained mixing and compaction temperature results are presented in Table 7. For PMB samples, the results showed a noticeable decrease in mixing and compaction temperatures. On the other hand, the obtained mixing and compaction temperatures for base bitumen are close to the

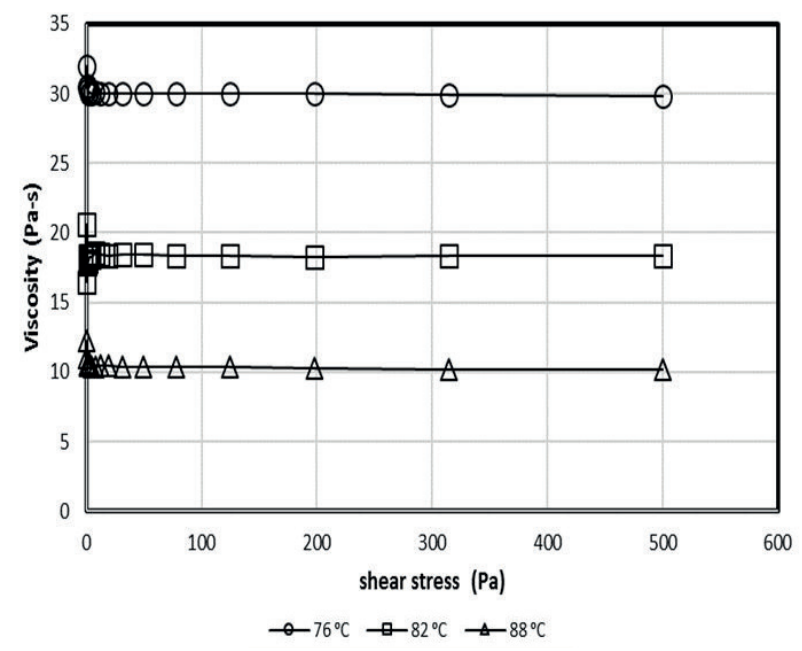

Fig. 11 Steady shear flow method for base bitumen

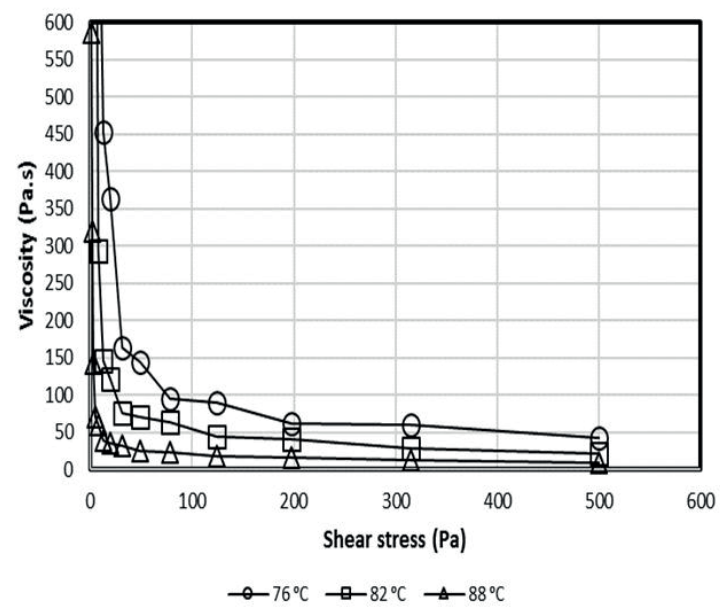

Fig. 12 Steady shear flow method for WMA (Organic)

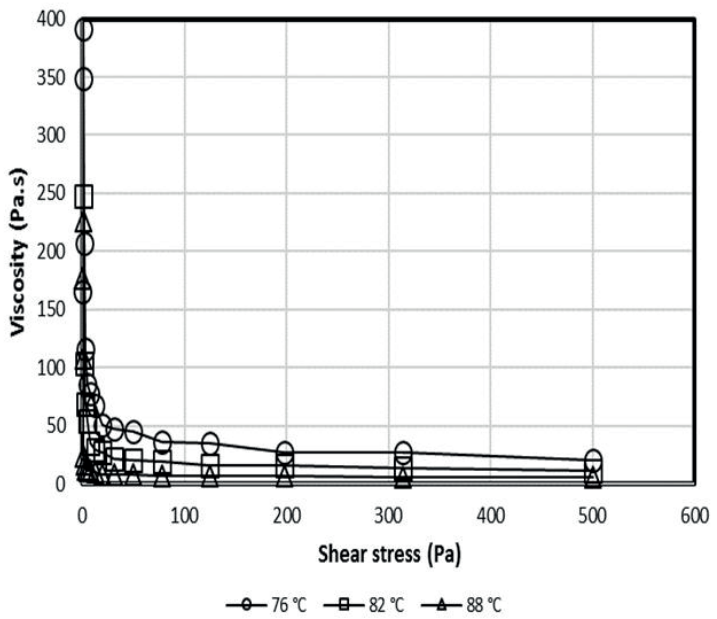

Fig. 13 Steady shear flow method for WMA (Chemical)

Equiviscous method. While the implementation of the SSF method for the warm mix (organic and chemical) bitumen samples has resulted in lower mixing and compaction temperatures compared to the Equiviscous method. 


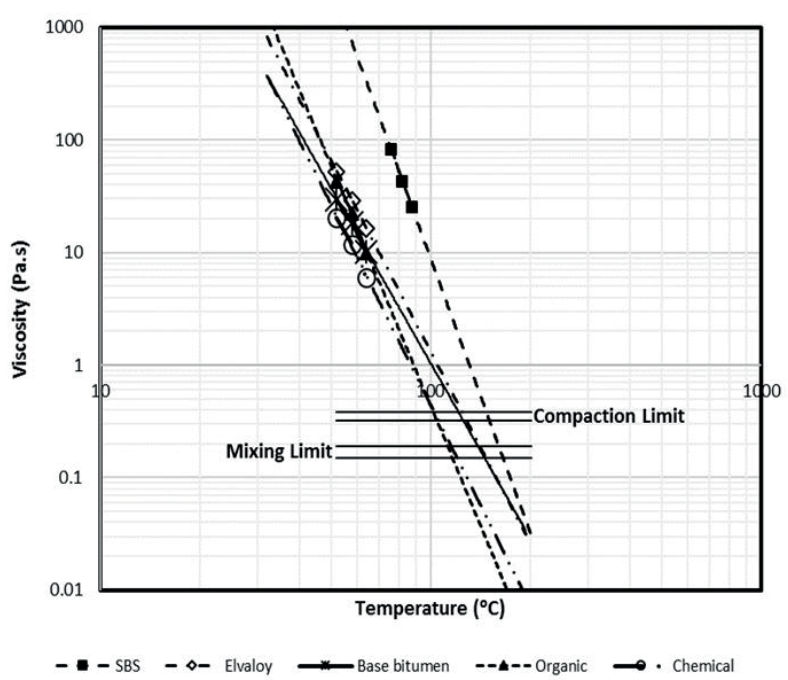

Fig. 14 Mixing and compaction temperatures calculation for SSF

\begin{tabular}{ccc}
\multicolumn{3}{c}{ Table 7 SSF method results } \\
\hline Material & $\begin{array}{c}\text { Mixing temperature } \\
\left({ }^{\circ} \mathrm{C}\right)\end{array}$ & $\begin{array}{c}\text { Compaction } \\
\text { temperature }\left({ }^{\circ} \mathrm{C}\right)\end{array}$ \\
\hline Base bitumen & 154 & 139 \\
PMB (SBS) & 166 & 148 \\
PMB (Elvaloy) & 157 & 142 \\
WMA (Organic) & 133 & 124 \\
WMA (Chemical) & 136 & 124 \\
\hline
\end{tabular}

\subsubsection{Phase Angle method}

This test is performed by measuring the frequency sweep of the bitumen sample by applying a range of frequencies from 0.1 to $100 \mathrm{rad} / \mathrm{sec}$. Phase angle master curve is developed by using Time-Temperature Superposition (TTS) procedure and utilizing $80{ }^{\circ} \mathrm{C}$ as a reference temperature as shown in Figs. 15-19.

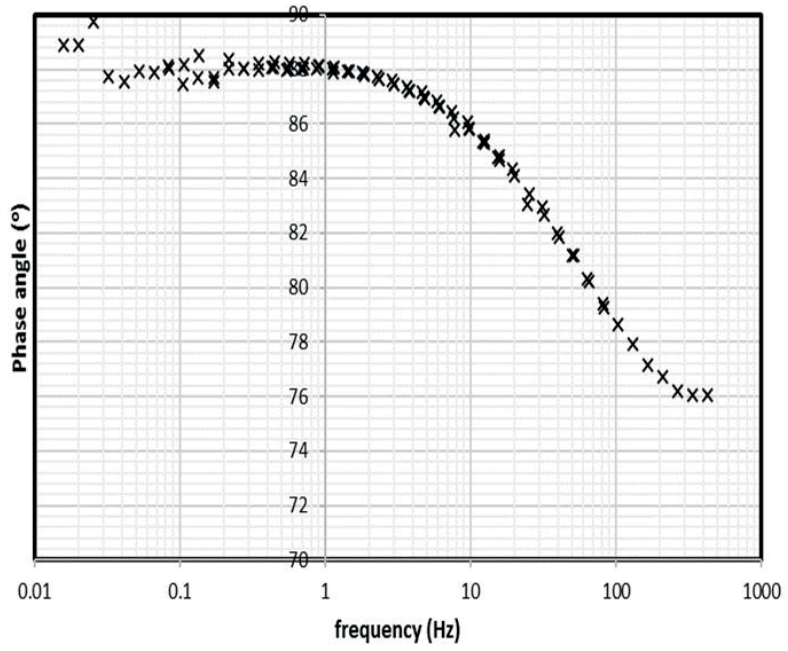

Fig. 15 Master curve for PMB (SBS)

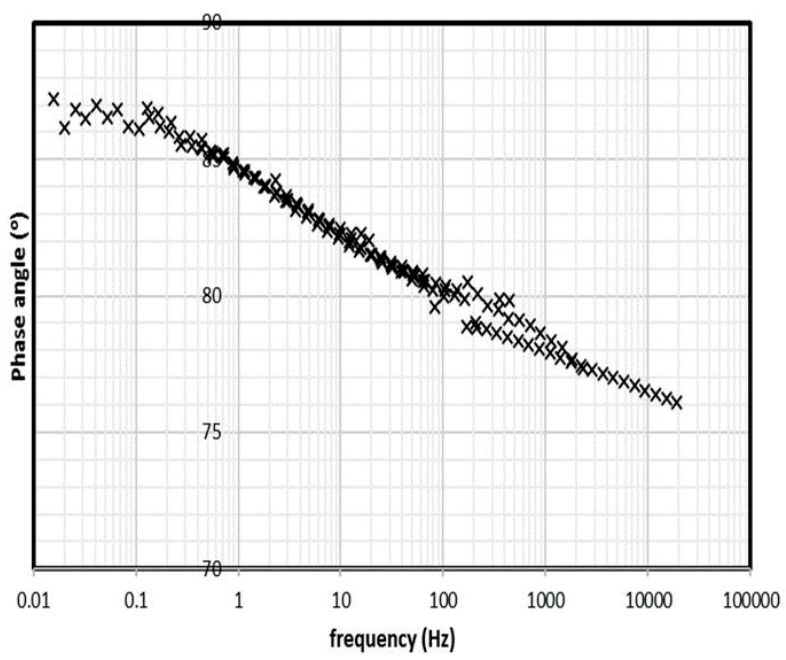

Fig. 16 Master curve for PMB (Elvaloy)

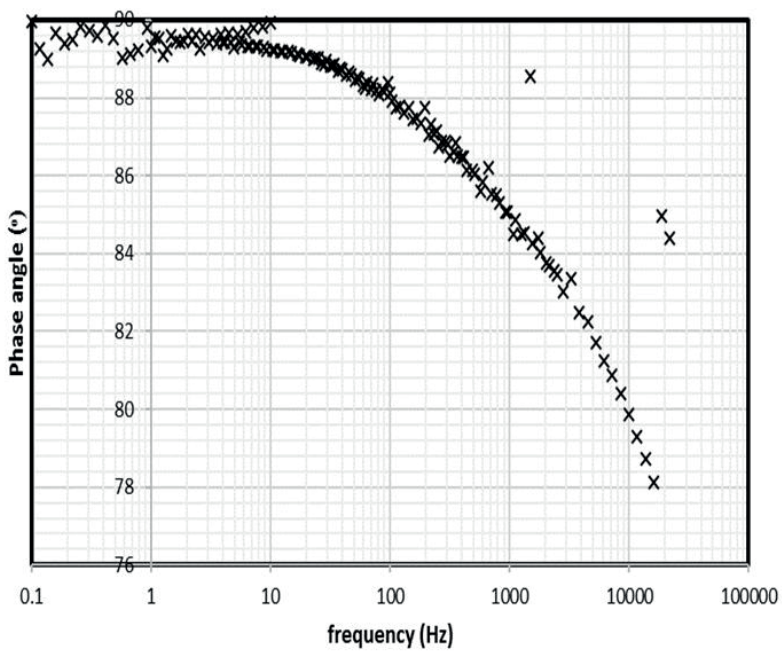

Fig. 17 Master curve for base bitumen

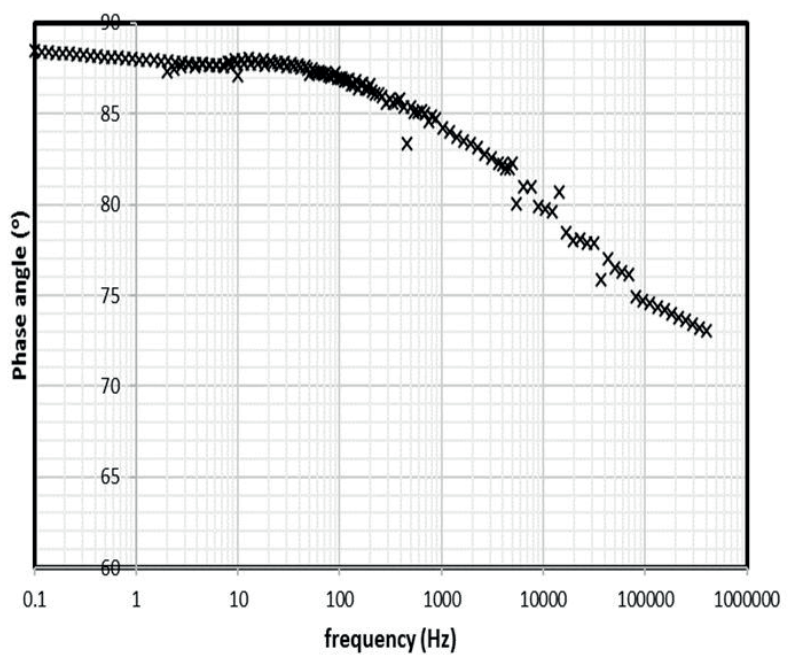

Fig. 18 Master curve for WMA (Organic) 


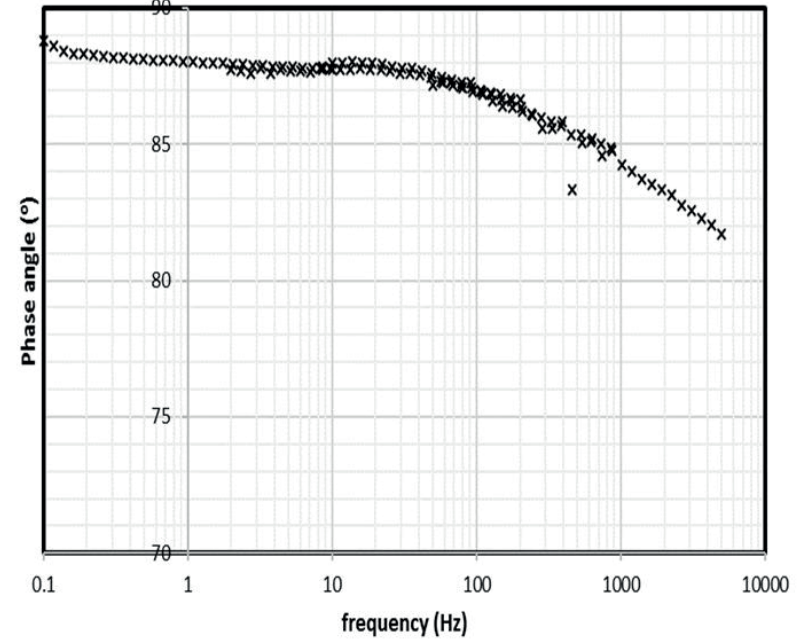

Fig. 19 Master curve for WMA (Chemical)

The mixing and compaction temperatures calculated using empirical equations and the obtained results are presented in Table 8. The application of this method for PMB samples also gave lower mixing and compaction temperatures than the Equiviscous method. While for base bitumen and WMA samples the obtained results showed slight differences with the Equiviscous method.

\section{Conclusions}

The standard method (Equiviscous method) for determining mixing and compaction temperatures is developed for base (unmodified) bitumen based on viscosity measurements conducted at a single shear rate value $(6.81 / \mathrm{s})$. The Equiviscous method application on PMB often requires heating to unrealistically high temperatures. Besides, The Equiviscous method application on WMA resulted in mixing and compaction temperatures that do not yield significant reduction.

This study aimed to investigate several procedures (HSR, ZSV, SSF, Phase angle) for determining mixing and compaction temperatures applicable for both unmodified

\section{References}

[1] Asphalt Institute Executive Offices and Research Center "Laboratory Mixing and Compaction Temperatures", [pdf] Asphalt Institute Technical Bulletin, Lexington, KY, USA, 2006. [online] Available at: https://docplayer.net/20993933-Asphalt-institute-technical-bulletin-laboratory-mixing-and-compaction temperatures.html [Accessed: 14 October 2019]

[2] ASTM "ASTM D2493 Standard Viscosity-Temperature Chart for Asphalts", American Society for Testing and Materials; West Conshohocken, PA, USA, 2010. https://doi.org/10.1520/D2493_D2493M-16
Table 8 phase angle method results

\begin{tabular}{lcc}
\hline Material & Mixing temperature $\left({ }^{\circ} \mathrm{C}\right)$ & $\begin{array}{c}\text { Compaction } \\
\text { temperature }\left({ }^{\circ} \mathrm{C}\right)\end{array}$ \\
\hline Base bitumen & 144 & 134 \\
PMB (SBS) & 155 & 142 \\
PMB (Elvaloy) & 161 & 148 \\
WMA (Organic) & 145 & 135 \\
WMA (Chemical) & 145 & 134.5 \\
\hline
\end{tabular}

and modified (with polymer as well as WMA additives) bitumen in hot mix asphalt. Among PMB samples, Zero Shear Viscosity (ZSV) demonstrated the lowest mixing and compaction temperatures. While for base (unmodified) bitumen, the proposed methods did not show a significant reduction in the mixing and compaction temperatures. This is due to the Newtonian behavior of such material. Whereas, for WMA, the application of the Steady Shear Flow (SSF) method seemed to generate lower mixing and compaction temperatures for WMA samples in compare to the standard methods.

\section{Recommendations}

The conclusion of this study covers the utilization of two types of polymer (SBS and Elvaloy) as well as Organic and Chemical WMA additives. More research should be carried out by using different penetration grade bitumen involving different kinds of polymers and WMA additives in order to perform more validation.

\section{Acknowledgment}

This research was sponsored by the Department of Scientific Research projects, Dokuz Eylul University under the project number 2019.KB.FEN.021 for which the authors are greatly indebted. The authors are also thankful to the Graduate School of Natural and Applied Sciences of Dokuz Eylul University for its support.

[3] Yildirim, Y., Solaimanian, M., Kennedy, T. W. "Mixing and compaction temperatures for hot mix asphalt concrete", Center for Transportation Research, Austin, TX, USA, Rep. 1250-5, 2000.

[4] Khatri, M. A. "Selection of Mixing and Compaction Temperatures for Hot Mix Asphalt Mixtures Produced with Modified Binders", $\mathrm{PhD}$ dissertation, University of Wisconsin-Madison, 2005.

[5] West, R. C., Watson, D. E., Turner, P. A., Casola, J. R. "Mixing and compaction temperatures of asphalt binders in hot-mix asphalt", National Cooperative Highway Research Program, Washington, DC, USA, Rep. 648, 2010. 
[6] Zeng, M., Wu, C. "Effects of Type and Content of Mineral Filler on Viscosity of Asphalt Mastic and Mixing and Compaction Temperatures of Asphalt Mixture", Transportation Research Record: Journal of the Transportation Research Board, 2051(1), pp. 31-40, 2008.

https://doi.org/10.3141/2051-05

[7] Azari, H., McCuen, R. H., Stuart, K. D. "Optimum Compaction Temperature for Modified Binders, 129(5), pp. 531-537, 2003. https://doi.org/10.1061/(ASCE)0733-947X(2003)129:5(531)

[8] Lee, S.-J., Amirkhanian, S. N., Kwon, S.-Z. "The effects of compaction temperature on CRM mixtures made with the SGC and the Marshall compactor", Construction and Building Materials, 22(6), pp. 1122-1128, 2008.

https://doi.org/10.1016/j.conbuildmat.2007.03.003

[9] Yaacob, H., Mughal, M. A., Jaya, R. P., Hainin, M. R., Jayanti, D. S., Wan, C. N. C. "Rheological properties of styrene butadiene rubber modified bitumen binder", Jurnal Teknologi, 78(7-2), pp. 121-126, 2016.

https://doi.org/10.11113/jt.v78.9503

[10] Che Norazman, C. W., Jaya, R. P., Hamzah, M. O. "Properties of Porous Asphalt Mixture Made with Styrene Butadiene Styrene under Long Term Oven Ageing", Advanced Materials Research, 486, pp. 378-383, 2012.

https://doi.org/10.4028/www.scientific.net/AMR.486.378

[11] Norhidayah, A. H., Mahmud, M. Z. H., Ramadhansyah, P. J. "Air Void Characterisation in Porous Asphalt Using X-Ray Computed Tomography", Advanced Materials Research, 911, pp. 443-448, 2014.

https://doi.org/10.4028/www.scientific.net/AMR.911.443

[12] ASTM "ASTM D5 - 06- Standard Test Method for Penetration of Bituminous Materials", ASTM International, West Conshohocken, PA, USA, 2006.

https://doi.org/10.1520/D0005-06

[13] ASTM "ASTM D36 / D36M - 14(2020)- Standard Test Method for Softening Point of Bitumen (Ring-and-Ball Apparatus)", ASTM International, West Conshohocken, PA, USA, 2020. https://doi.org/10.1520/D0036_D0036M-14R20

[14] ASTM "ASTM D113-17- Standard Test Method for Ductility of Asphalt Materials", ASTM International, West Conshohocken, PA, USA, 2017.

https://doi.org/10.1520/D0113-17

[15] ASTM "ASTM D70-03 - Standard Test Method for Specific Gravity and Density of Semi-Solid Bituminous Materials (Pycnometer Method)", ASTM International, West Conshohocken, PA, USA, 2003.

https://doi.org/10.1520/D0070-03

[16] ASTM "ASTM D92-18 - Standard Test Method for Flash and Fire Points by Cleveland Open Cup Tester", ASTM International, West Conshohocken, PA, USA, 2018. https://doi.org/10.1520/D0092-18

[17] ASTM "ASTM D2872-19 - Standard Test Method for Effect of Heat and Air on a Moving Film of Asphalt (Rolling Thin-Film Oven Test)", ASTM International, West Conshohocken, PA, USA, 2019. https://doi.org/10.1520/D2872-19
[18] Capitão, S. D., Picado-Santos, L. G., Martinho, F. "Pavement engineering materials: Review on the use of warm-mix asphalt", Construction and Building Materials, 36, pp. 1016-1024, 2012. https://doi.org/10.1016/j.conbuildmat.2012.06.038

[19] Rubio, M. C., Martínez, G., Baena, L., Moreno, F. "Warm mix asphalt: an overview", Journal of Cleaner Production, 24, pp. 76-84, 2012. https://doi.org/10.1016/j.jclepro.2011.11.053

[20] Zettler, R. "Warm mix stands up to its trials", Better Roads, 76(2), pp. 16-18, 2006.

[21] Sengoz, B., Topal, A., Oner, J., Yilmaz, M., Dokandari, P. A., Kok, B. V. "Performance Evaluation of Warm Mix Asphalt Mixtures with Recycled Asphalt Pavement", Periodica Polytechnica Civil Engineering, 61(1), pp. 117-127, 2016.

https://doi.org/10.3311/PPci.8498

[22] Mo, L., Li, X., Fang, X., Huurman, M., Wu, S. "Laboratory investigation of compaction characteristics and performance of warm mix asphalt containing chemical additives", Construction and Building Materials, 37, pp. 239-247, 2012.

https://doi.org/10.1016/j.conbuildmat.2012.07.074

[23] Tóth, Cs., Primusz, P. "New Hungarian Mechanistic-Empirical Design Procedure for Asphalt Pavements", Baltic Journal of Road and Bridge Engineering, 15(1), pp. 161-186, 2020.

https://doi.org/10.7250/bjrbe.2020-15.466

[24] ASTM "ASTM D792-20- Standard Test Methods for Density and Specific Gravity (Relative Density) of Plastics by Displacement", ASTM International, West Conshohocken, PA, USA, 2020. https://doi.org/10.1520/D0792-20

[25] ASTM "ASTM D412-16 - Standard Test Methods for Vulcanized Rubber and Thermoplastic Elastomers-Tension", ASTM International, West Conshohocken, PA, USA, 2016. https://doi.org/10.1520/D0412-16

[26] ASTM "ASTM D2240-15e1 - Standard Test Method for Rubber Property-Durometer Hardness", ASTM International, West Conshohocken, PA, USA, 2015. https://oi.org/10.1520/D2240-15E01

[27] ASTM "ASTM D1238-20 - Standard Test Method for Melt Flow Rates of Thermoplastics by Extrusion Plastometer", ASTM International, West Conshohocken, PA, USA, 2020. https://doi.org/10.1520/D1238-20

[28] Sengoz, B., Isikyakar, G. "Analysis of styrene-butadiene-styrene polymer modified bitumen using fluorescent microscopy and conventional test methods", Journal of Hazardous Materials, 150(2), pp. 424-432, 2008. https://doi.org/10.1016/j.jhazmat.2007.04.122

[29] Munera, J. C., Ossa, E. A. "Polymer modified bitumen: Optimization and selection", Materials \& Design (1980-2015), 62, pp. 91-97, 2014.

https://doi.org/10.1016/j.matdes.2014.05.009

[30] Larsen, D. O., Alessandrini, J. L., Bosch, A., Cortizo, M. S. "Microstructural and rheological characteristics of SBS-asphalt blends during their manufacturing", Construction and Building Materials, 23(8), pp. 2769-2774, 2009.

https://doi.org/10.1016/j.conbuildmat.2009.03.008 
[31] Schaur, A., Unterberger, S., Lackner, R. "Impact of molecular structure of SBS on thermomechanical properties of polymer modified bitumen", European Polymer Journal, 96, pp. 256-265, 2017. https://doi.org/10.1016/j.eurpolymj.2017.09.017

[32] Kök, B. V., Yilmaz, M., Çakiroğlu, M., Kuloğlu, N., Şengür, A. "Neural network modeling of SBS modified bitumen produced with different methods", Fuel, 106, pp. 265-270, 2013. https://doi.org/10.1016/j.fuel.2012.12.073

[33] Topal, A. "Evaluation of the properties and microstructure of plastomeric polymer modified bitumens", Fuel Processing Technology, 91(1), pp. 45-51, 2010.

https://doi.org/10.1016/j.fuproc.2009.08.007

[34] Bulatović, V. O., Rek, V., Marković, K. J. "Effect of polymer modifiers on the properties of bitumen", Journal of Elastomers \& Plastics, 46(5), pp. 448-469, 2014. https://doi.org/10.1177/0095244312469964

[35] Oliveira, J. R. M., Silva, H. M. R. D., Abreu, L. P. F., Fernandes, S. R. M. "Use of a warm mix asphalt additive to reduce the production temperatures and to improve the performance of asphalt rubber mixtures", Journal of Cleaner Production, 41, pp. 15-22, 2013. https://doi.org/10.1016/j.jclepro.2012.09.047
[36] Kanitpong, K., Nam, K., Martono, W., Bahia, H. "Evaluation of a warm-mix asphalt additive", Proceedings of the Institution of Civil Engineers - Construction Materials, 161(1), pp. 1-8, 2008. https://doi.org/10.1680/coma.2008.161.1.1

[37] Sengoz, B., Topal, A., Gorkem, C. "Evaluation of natural zeolite as warm mix asphalt additive and its comparison with other warm mix additives", Construction and Building Materials, 43, pp. 242-252, 2013.

https://doi.org/10.1016/j.conbuildmat.2013.02.026

[38] Yildirim, Y., Ideker, J., Hazlett, D. "Evaluation of Viscosity Values for Mixing and Compaction Temperatures", Journal of Materials in Civil Engineering, 18(4), pp. 545-553, 2006. https://doi.org/10.1061/(ASCE)0899-1561(2006)18:4(545)

[39] Reinke, G. "Determination of Mixing and Compaction Temperature of Pg Binders Using a Steady Shear Flow Test", [pdf] MTE Service, Perm, Russian Federation, 2004. Available at: https:/engineering. purdue.edu/ spave/old/Technical\%20Info/Meetings/Binder\%20 ETG\%20Sept $\% 2003 \% 20$ Las\%20Vegas,\%20NV/Reinke_MIX\%20 AND\%20COMPACTINO\%20INFO\%20FOR\%20ETG\%209-1503.pdf [Accessed: 14 October 2019] 